\title{
The association between intracranial pressure and optic nerve sheath diameter on patients with head trauma
}

\author{
Associação entre a pressão intracraniana e o diâmetro da bainha do nervo óptico em \\ pacientes com traumatismo cranioencefálico
}

Kaan ÇELIK', Bekir Enes DEMIRYUREK²

\begin{abstract}
Background: Although intracranial pressure (ICP) monitoring is the gold standard method for measuring intracranial pressure after traumatic brain injury, optic nerve sheath diameter (ONSD) measurement with ultrasound (US) is also used in the evaluation of ICP. Objective: To investigate the association between a series of OSND measurements by US and changes in clinical presentation of the patient. Methods: Prospective study including 162 patients with traumatic brain injury. Age, sex, cerebral CT findings, ONSD levels by US at minutes 0,60, and 120, Glasgow Coma Scale (GCS) within same period, change of consciousness, treatment, and mortality data were reviewed. The association of ONSD levels with GCS, change of consciousness, treatment, and mortality was evaluated. Results: There was no difference in ONSD changes in the patients' sample within the period ( $p=0.326)$. ONSD significantly increased in patients who died $(p<0.001)$, but not in those who survived ( $p=0.938)$. There was no significant change in ONSD of the patients who received anti-edema therapy ( $p=801$ ), but significantly increased ONSD values were found in those who received anti-edema therapy $(p=0.03)$. Patients without change of consciousness did not have any significant change in ONSD ( $p=0.672)$, but ONSD values increased in patients who consciousness became worse, and decreased in those who presented a recovery (respectively, $p<0.001, p=0.002$ ). A negative correlation was detected between ONSD values and GSC values measured at primary, secondary, and tertiary time periods (for all $p<0.001$ ). Conclusions: ONSD follow-up may be useful to monitor ICP increase in patients with acute traumatic brain injury.
\end{abstract}

Keywords: Brain Injuries, Traumatic; Optic Nerve Neoplasms; Glasgow Coma Scale; Mortality.

\section{RESUMO}

Antecedentes: Embora o monitoramento da pressão intracraniana (PIC) seja o método padrão-ouro para medir a pressão intracraniana após lesão encefálica traumática, a medição do diâmetro da bainha do nervo óptico (DBNO) com ultrassom (US) também é usada na avaliação da PIC. Objetivo: Investigar a associação entre uma série de medidas de DBNO por US e mudanças na apresentação clínica do paciente. Métodos: Estudo prospectivo incluindo 162 pacientes com traumatismo cranioencefálico. Idade, sexo, achados de TC cerebral, níveis de DBNO por US nos minutos 0, 60 e 120, Escala de Coma de Glasgow (GCS) no mesmo período, mudança de consciência, tratamento e dados de mortalidade foram revisados. A associação dos níveis de DBNO com GCS, mudança de consciência, tratamento e mortalidade foi avaliada. Resultados: Não houve diferença nas mudanças de DBNO na amostra de pacientes no período ( $p=0,326)$. 0 DBNO aumentou significativamente em pacientes que morreram ( $p<0,001$ ), mas não naqueles que sobreviveram ( $p=0,938$ ). Não houve mudança significativa no DBNO dos pacientes que receberam terapia antiedema $(p=801)$, mas valores significativamente aumentados de DBNO foram encontrados naqueles que receberam terapia antiedema $(p=0,03)$. Pacientes sem alteração da consciência não tiveram alteração significativa no DBNO $(p=0,672)$, mas os valores do DBNO aumentaram nos pacientes que pioraram a consciência e diminuíram naqueles que apresentaram recuperação (respectivamente, $\mathrm{p}<0,001, \mathrm{p}=0,002$ ). Detectou-se correlação negativa entre os valores de DBNO e os valores de GSC medidos nos períodos primário, secundário e terciário (para todos, p<0,001). Conclusões: 0 acompanhamento do DBNO pode ser útil para monitorar o aumento da PIC em pacientes com lesão cerebral traumática aguda.

Palavras-chave: Lesões Encefálicas Traumáticas; Neoplasias do Nervo Óptico; Escala de Coma de Glasgow; Mortalidade.

\footnotetext{
'Abant Izzet Baysal University Education and Research Hospital, Department of Emergency, Bolu, Turkey.

${ }^{2}$ Abant Izzet Baysal University Education and Research Hospital, Department of Neurology, Bolu, Turkey.

KC (D) https://orcid.org/0000-0002-9664-6732; BED (D) https://orcid.org/0000-0003-4221-2506

Correspondence: Bekir Enes Demiryürek; Email: bekirenes10@gmail.com.

Conflict of interest: There is no conflict of interest to declare.
}

Authors' contributions: BED, KCุ: contributed substantially to the conception or design of the study; KCุ: contributed to the collection, analysis, or interpretation of data; BED, KCุ: contributed to the writing or critical review of the manuscript; BED, KCุ: contributed to the approval of the final version to be published.

Received on October 14, 2020; Received in its final form on November 04, 2020; Accepted on November 09, 2020. 


\section{INTRODUCTION}

Traumatic brain injury (TBI) is a health condition that affects the whole society and especially young adults. TBI is responsible from one third of trauma-related deaths ${ }^{1,2}$.

TBI may develop due to primary effect of the trauma or as a result of secondary effects such as hypoxia, hyperkapnia, hypotension, increase in intracranial pressure, and hyperglycemia $^{3}$. Although it is not possible to avoid primary TBI due to acute effects of the impact, brain damage may be reduced by minimizing metabolic causes and cerebral edema in secondary injuries. The cause for brain edema developed after secondary injury is vasogenic, and this induces cytotoxic edema and causes increase in intracranial pressure (ICP). On the other hand, increased ICP may cause more edema due to decrease in cerebral perfusion. If it is not intervened, it may progress to herniation and death. Therefore, detection and monitoring of ICP has a vital importance $e^{4,5,6}$.

Although ICP monitoring is the gold standard approach, it is an invasive procedure and often it cannot be performed due to complications and requirement of technical equipment ${ }^{7,8}$. It has been specified that the optic nerve sheath diameter (ONSD) increases along with the increase of ICP due to the extension of the dura mater surrounding the optic nerve, and the most adequate measurement site is $3 \mathrm{~mm}$ distant from the distal side of the ocular globe ${ }^{6,7}$. Several studies were conducted through brain tomography (CT), magnetic resonance imaging, and ultrasound (US) and consistent results were obtained ${ }^{9,10,11,12}$. A meta-analysis stated that ONSD thickness wider than $5 \mathrm{~mm}$ measured by US is an indicator for the increase in ICP, and sensitivity and specificity of such measurement are 99 and $77 \%$, respectively ${ }^{13}$.

The aim of this study was to investigate the association between a series of ONSD measurements by US and changes in clinical presentation of patients.

\section{METHODS}

This study was conducted prospectively on 162 adult patients with TBI following approval of the local ethical committee of Medical Faculty within Abant Izzet Baysal University.

\section{Patient selection}

One hundred and sixty-two adult patients who were monitored due to TBI between January, $1^{\text {st }}, 2020$ and June, $1^{\text {st }}$, 2020 were prospectively reviewed.

Patients with metabolic, orbital, or intracranial pathology that may cause the increase of ONSD, patients $<18$ years old, patients with indication of urgent surgery who were monitored in the emergency clinic for less than 2 hours, patients with isolated cranial fracture, and those who have rejected to give consent were excluded from the study.
Age, sex, cerebral CT findings, ONSD levels by US at minutes 0, 60, and 120, Glasgow Coma Scale (GCS) within same period, change of consciousness, treatment, and mortality data of patients were reviewed. The association of ONSD levels with GCS scores, change of consciousness, treatment, and mortality was evaluated.

\section{Optic nerve sheath diameter measurement method}

The ONSD measurement was performed by a well-trained emergency medicine specialist certificated by the Health Minister of Turkey using a $7.5 \mathrm{MHz}$ linear probe. A thin layer of gel was applied on both eyes of the patient lying in the supine position. ONSD was measured with a Sonosite Plus 180 model linear transducer US machine $3 \mathrm{~mm}$ posterior to the eye globe at sagittal and transverse positions. The averages ONSD of transverse and sagittal measurements on the right and left eyes were calculated.

\section{Statistical analysis}

Data analysis was performed with the Statistical Package for the Social Sciences (SPSS) version 22 program. Median and interquartile range (IQR) were used to demonstrate quantitative data; qualitative data were expressed in number of cases (n) and percentile (\%). The distribution of quantitative data was evaluated by Kolmogorov Smirnov test. Time-dependent changes in numeric variables were analyzed by Friedman Test. The Wilcoxon test was utilized to detect significant differences. Detection of significance of repetitive measurements and affecting factors was performed through the Greenhouse-Geisser analysis. Mann-Whitney U test was used to analyze the differences in measurement values between two groups. Pearson's chisquare test was utilized for analysis of categorical variables. Correlation between time-dependent changes of two different numeric variables was analyzed through Spearman's Correlation test. A $\mathrm{p}<0.05$ was accepted as significant.

\section{RESULTS}

Median age of the patients was 34 (IQR: 45) years; $73.5 \%$ $(\mathrm{n}=119)$ of the patients were male. The mortality rate was 9.9\% $(n=16)$. There was no association of mortality with age and gender (respectively $\mathrm{p}=0.668, \mathrm{p}=0.563$ ). The most common form of injury was in-vehicle traffic accident (IVTA) (44.4\%); penetrating injury was the most common $(\mathrm{p}<0.001)$ cause of death. The most common imaging findings were subarachnoid bleeding (58\%) and subdural hematoma (27.8\%). Mortality was significantly higher in patients with bone fracture and epidural hematoma (respectively, $\mathrm{p}=0.015$, $\mathrm{p}<0.001$ ). Prevalence of patients without change in consciousness within 2 hours was high, and clinical presentation of patients how died worsened within 2 hours ( $<<0.001$ ). Anti-edema therapy frequency was significantly higher in 
patients who survived $(\mathrm{p}=0.007)$. There was no significant difference in patients who died at referral even with higher ONSD values $(\mathrm{p}=0.941)$. The differences in ONSD between 60 and 120 minutes, 0 and 60 minutes, 60 and 120 minutes, and 0 and 120 minutes were significantly higher in patients who died (respectively $\mathrm{p}=0.006, \mathrm{p}<0.001, \mathrm{p}<0.001, \mathrm{p}=0.013$, $\mathrm{p}<0.001)$. There was a significantly higher difference in GCS scores between 0 and 60 minutes, 60 and 120 minutes, and 0 and 120 minutes in patients who died (for all; $p<0.05$ ). GCS scores difference between 0 minutes and 60 minutes was similar between patients who died and those who survived $(\mathrm{p}=0.05)$ (Table 1$)$.

There was no difference in time-dependent ONSD changes in the patients of our study $(p=0.326)$. It was detected that mortality was associated with change in ONSD $(\mathrm{p}<0.001)$. Anti-edema treatment did not significantly affect ONSD change $(p=0.05)$. Change of consciousness was significantly associated with change in ONSD $(\mathrm{p}<0.001)$ (Table 2).

There was no difference in ONSD change in the patients of our study within the time period ( $\mathrm{p}=0.102)$. ONSD significantly increased in patients who died $(\mathrm{p}<0.001)$, and there was no change in patients who survived ( $\mathrm{p}=0.938$ ). ONSD did not vary in patients who received anti-edema therapy ( $\mathrm{p}=0.831$ ), but it significantly increased in those who did not received anti-edema therapy ( $\mathrm{p}=0.03$ ). Patients without change of consciousness did not have a significant change in ONSD ( $p=0.672)$; ONSD values increased in patients who

Table 1. Clinical and demographic characteristics of patients.

\begin{tabular}{|c|c|c|c|c|c|}
\hline & & Total $(n=162)$ & Alive $(n=146)$ & Dead $(n=16)$ & $\mathrm{p}$-value \\
\hline Age, median (IQR) & & $34(45)$ & $30(42)$ & $48(68)$ & 0.668 \\
\hline \multirow{2}{*}{ Sex, n (\%) } & Male & $119(73.5)$ & $106(72.6)$ & $13(81.3)$ & \multirow{2}{*}{0.563} \\
\hline & Female & $43(26.5)$ & $40(27.4)$ & $3(18.8)$ & \\
\hline \multirow{5}{*}{ Mechanism of trauma, n (\%) } & Off-vehicle traffic accident & $26(16)$ & $23(15.8)$ & $3(18.8)$ & \multirow{5}{*}{$<0.001$} \\
\hline & IVTA & $72(44.4)$ & $67(45.9)$ & 5 (31.3) & \\
\hline & Firearm injury & $5(3.1)$ & $0(0)$ & 5 (31.3) & \\
\hline & Pounding & $28(17.3)$ & $27(18.5)$ & $1(6.3)$ & \\
\hline & High fall & $31(19.1)$ & $29(19.9)$ & $2(12.5)$ & \\
\hline \multirow{6}{*}{ CT findings, $n(\%)$} & Bone fracture & $45(27.8)$ & $36(24.7)$ & $9(56.3)$ & 0.015 \\
\hline & Epidural hematoma & $34(21)$ & $24(16.4)$ & $10(62.5)$ & $<0.001$ \\
\hline & Subdural hematoma & $48(29.6)$ & $44(30.1)$ & $4(25)$ & 0.780 \\
\hline & Subarachnoid hemorrhage & $94(58)$ & $84(57.5)$ & $10(62.5)$ & 0.794 \\
\hline & Contusion & $38(23.5)$ & $33(22.6)$ & 5 (31.3) & 0.534 \\
\hline & Cerebral edema & $24(14.8)$ & $20(13.7)$ & $4(25)$ & 0.262 \\
\hline \multirow{3}{*}{ Change of consciousness, n (\%) } & None & $128(79)$ & $122(83.6)$ & $6(37.5)$ & \multirow{3}{*}{$<0.001$} \\
\hline & Negative & $23(14.2)$ & $13(8.9)$ & $10(62.5)$ & \\
\hline & Positive & $11(6.8)$ & $11(7.5)$ & $0(0)$ & \\
\hline \multirow{2}{*}{ Anti-edema therapy, n (\%) } & Present & $114(70.4)$ & $108(74)$ & $6(37.5)$ & \multirow{2}{*}{0.007} \\
\hline & none & $48(29.6)$ & $38(26)$ & $10(62.5)$ & \\
\hline \multirow{6}{*}{ ONSD, median (IQR) } & Minute 0 & $6.60(1.2)$ & $6.40(0.6)$ & $6.60(1.2)$ & 0.941 \\
\hline & Minute 60 & $6.50(1.2)$ & $6.50(1.2)$ & $6.70(0.2)$ & 0.006 \\
\hline & Minute 120 & $6.50(1.2)$ & $6.45(1.2)$ & $6.7(0.2)$ & $<0.001$ \\
\hline & Difference between minutes 0 and 60 & $0(0)$ & $0(0)$ & $0.2(0)$ & $<0.001$ \\
\hline & Difference between 60 and 120 & $0(0.10)$ & $0(0.1)$ & $0(0.3)$ & 0.013 \\
\hline & Difference between minutes 0 and 120 & $0(0.2)$ & $0(0.2)$ & $0.4(0.85)$ & $<0.001$ \\
\hline \multirow{6}{*}{ GCS, median (IQR) } & Minute 0 & $9(1)$ & $9(1)$ & $5.5(3)$ & $<0.001$ \\
\hline & Minute 60 & $9(1)$ & $9(1)$ & $5(3.8)$ & $<0.001$ \\
\hline & Minute 120 & $9(1)$ & $9(1)$ & $4.5(2.75)$ & $<0.001$ \\
\hline & Difference between minutes 0 and 60 & $0(0)$ & $0(0)$ & $0(0)$ & 0.050 \\
\hline & Difference between minutes 60 and 120 & $0(0)$ & $0(0)$ & $-1(2)$ & $<0.001$ \\
\hline & Difference between minutes 0 and 120 & $0(0)$ & $0(0)$ & $-1.5(2.75)$ & $<0.001$ \\
\hline
\end{tabular}

IQR: interquartile range; ONSD: optic nerve sheath diameter; GCS: Glasgow Coma Scale. 
consciousness became worse, and decreased in those who presented recovery (respectively; $\mathrm{p}<0.001, \mathrm{p}=0.002$ ) (Table 3 ).

A negative correlation was detected between ONSD values and GSC values measured at primary, secondary, and tertiary time periods (for all $\mathrm{p}<0.001$ ). Furthermore, a negative correlation was detected between ONSD values differences and GCS scores differences measured within the same time periods ( for all $\mathrm{p}<0.001$ ) (Table 4).

\section{DISCUSSION}

Non-invasive ICP measurement techniques have been sought to replace the invasive measurement, which is accepted as the gold standard, but causes complications (infection, hematoma, etc.) in 5\% of cases, cannot be applied in many centers, and cannot be used in bleeding disorders and extremely high brain pressures ${ }^{9}$. Fortunately,

Table 2. Optic nerve sheath diameter change within the study period.

\begin{tabular}{lccccc} 
& Type III sum of squares & df & Mean square & $F$ & $p$-value \\
\hline Totally & 0.069 & 1.500 & 0.046 & 1.078 & 0.326 \\
Mortality & 2.033 & 1.633 & 1.245 & 39.037 & $<0.001$ \\
\hline Anti-edema therapy & 0.212 & 1.498 & 0.142 & 3.348 & 0.050 \\
Change of consciousness & 2.316 & 3.288 & 0.704 & 22.877 & $<0.001$ \\
\hline
\end{tabular}

Table 3. Optic nerve sheath diameter change and differences within the period 0,60, and 120 minutes.

\begin{tabular}{|c|c|c|c|c|c|}
\hline & & $\begin{array}{c}0 \text { minute } \\
\text { Median (IQR) }\end{array}$ & $\begin{array}{c}60 \text { minutes } \\
\text { Median (IQR) }\end{array}$ & $\begin{array}{c}120 \text { minutes } \\
\text { Median (IQR) }\end{array}$ & $\mathrm{p}$-value \\
\hline Totally & & $6.6(1.2)$ & $6.5(1.2)$ & $6.5(1.2)$ & 0.102 \\
\hline \multirow{2}{*}{ Mortality } & Alive & $6.6(1.2)$ & $6.5(1.2)$ & $6.45(1.2)$ & 0.938 \\
\hline & Dead & $6.4(0.6)$ & $6.7(0.2)$ & $6.7(0.2)$ & $<0.001^{a b c}$ \\
\hline \multirow{2}{*}{ Anti-edema therapy } & Receiving & $6.55(1.2)$ & $6.5(1.2)$ & $6.5(1.2)$ & 0.801 \\
\hline & Not receiving & $6.55(1.2)$ & $6.6(1.3)$ & $6.6(1.2)$ & $0.003^{a c}$ \\
\hline \multirow{3}{*}{ Change of consciousness } & None & $6.6(1.2)$ & $6.5(1.2)$ & $6.5(1.2)$ & 0.672 \\
\hline & Negative & $6.2(1.2)$ & $6.7(1.0)$ & $6.7(0.4)$ & $<0.001^{a b c}$ \\
\hline & Positive & $6.5(1.5)$ & $6.2(1.5)$ & $5.9(1.5)$ & $0.002^{b c}$ \\
\hline
\end{tabular}

${ }^{a} p<0.05$ for changes between 0 and 60 minutes; $b<0.05$ for changes between 60 and 120 minutes; ${ }^{p} p<0.05$ for changes between 0 and 120 minutes.

Table 4. Association between Glasgow Coma Scale and optic nerve sheath diameter.

\begin{tabular}{|c|c|c|c|c|c|c|c|c|}
\hline & & & & & & GCS & & \\
\hline & & & Minute 0 & Minute 60 & Minute 120 & $\begin{array}{c}\text { The difference } \\
\text { between minutes } \\
0 \text { and } 60\end{array}$ & $\begin{array}{c}\text { The difference } \\
\text { between minutes } \\
60 \text { and } 120\end{array}$ & $\begin{array}{c}\text { The difference } \\
\text { between minutes } \\
0 \text { and } 120\end{array}$ \\
\hline & Minuto & r & -0.231 & & & & & \\
\hline & IVIIIU⿴囗十 & $p$ & 0.003 & & & & & \\
\hline & & r & & -0.378 & & & & \\
\hline & IVIIIUCE OO & $p$ & & $<0.001$ & & & & \\
\hline & Minuts 120 & r & & & -0.485 & & & \\
\hline & & $p$ & & & $<0.001$ & & & \\
\hline ONSD & The difference & r & & & & -0.269 & & \\
\hline & 0 and 60 & $p$ & & & & 0.001 & & \\
\hline & The difference & r & & & & & -0.303 & \\
\hline & 60 and 120 & $p$ & & & & & $<0.001$ & \\
\hline & The difference & r & & & & & & -0.498 \\
\hline & 0 and 120 & $\mathrm{p}$ & & & & & & $<0.001$ \\
\hline
\end{tabular}

GCS: Glasgow Coma Scale; ONSD: optic nerve sheath diameter. 
it has been shown to be consistent with measurements made by $\mathrm{US}^{10}$.

The elevation of ONSD due to the increase of ICP in patients with TBI was shown in several studies ${ }^{11,12,13,14}$. Although the importance of urgent intervention for ICP increase, there is no method developed for ICP monitoring in the emergency clinic including the acute trauma period.

Many studies have shown that adult men are more exposed to trauma ${ }^{15,16,17,18}$. Mortality prevalence was reported to be independent from gender in many studies, but there are conflicting findings on the association between the age and mortality ${ }^{15,19,20}$. Unlu et al. reported that mortality is not dependent on age ${ }^{15}$; Kara et al. stated that trauma in elderly has high mortally ${ }^{20}$; and Adiyaman et al. found that age is a significant factor for mortality in the long-term ${ }^{19}$. In line with the literature, young males were more frequent in our study. There was no significant association of mortality with age and gender. Since adult males usually drive more and are more involved in social life as well as violence episodes such as fights and firearm injury, we believe that they are more exposed to trauma than women. Although age is associated with increased mortality due to natural increased catabolism and co-morbidities, we believe that age and sex contribute to the association because the main factor determining mortality is trauma severity, and men are more exposed to traumatic events than women.

Many studies show that TBI is commonly caused by traffic accidents ${ }^{21,22}$. Motorized vehicle accidents are responsible for the majority of TBI-associated deaths among young adults $^{2,23}$. Dur et al. stated that mortality due to high falls and traffic accidents are the most common in trauma patients admitted to the intensive care unit; however, no statistical significance was reported ${ }^{24}$. Kara et al. reported no association between mortality and type of trauma ${ }^{20}$. Although the most common form of injury was traffic accident in line with the literature, TBI was detected more in penetrating injuries. This may be related to the higher damage on the brain tissue in firearm injury cases.

Previous studies stated that the most common TBI cases are subarachnoid hemorrhage (SAH) and subdural hematoma $^{25,26}$. Siwicka-Gieroba et al. reported that patients with TBI developed SAH and epidural and subdural hematoma; however, deaths commonly occurred due to intracranial hemorrhage ${ }^{27}$. A study conducted on patients with TBI specified that death cases have higher hemorrhage and shifts and pressure on basal cysterns ${ }^{28}$. In this study, the most common TBI was SAH and subdural hematoma; TBI leading to death was more common in patients with epidural hemorrhage and bone fracture. Depending on the severity of the trauma, the risk of rupture of venous formations can be higher, thus increasing the death rate in SAH and subdural hemorrhage. However, we believe that the mortality rate increased due to trauma and bone fracture severity and the interruption of the bone integrity in firearm injuries followed by the damage to the brain tissue by bone fragments. Furthermore, epidural hemorrhage might progress to death because of arterial origin and concomitant bone fractures indicating the high energy trauma.

Previous studies stated that ONSD is over $5 \mathrm{~mm}$ when ICP is over $20 \mathrm{mmHg}$; ONSD of patients with TBI elevated up to 6.3 to $6.4 \mathrm{~mm}^{29,30,31}$. Moreover, ONSD is higher in patients with lower GCS, higher ICP, and in those who die from the injury ${ }^{7,31,32,33}$. A previous study conducted on patients with TBI reported that death cases have lower GCS and higher $\mathrm{ONSD}^{28}$. Sekhon et al. indicated in their study that every increase of $1 \mathrm{~mm}$ in ONSD doubles the risk of death ${ }^{7}$. In line with the literature, we also detected that death cases had lower GCS and higher ONSD.

Along with primary TBI, secondary injuries may cause cerebral edema, increase in ICP, and deterioration of the clinical presentation ${ }^{5,34,35}$. Studies reported that ONSD is an independent factor for morbidity and mortality, and monitoring of ICP and performance of required interventions are associated with lower rates of mortality ${ }^{36,37}$. Thotakura et al. performed ONSD measurement on adults with head trauma in an interval of 24 to 48 hours and reported that patients with a decreasing trend in ONSD values presented a good clinical progress, and none of them were treated surgically $^{38}$. In the present study, patients who died had lower GCS, worse clinical progress, and elevated ONSD values. ONSD significantly increased in patients who died and/or presented worsening clinical progress. There was no significant change in ONSD values of survivors. We believe that ICP increased within a short period due to primary or secondary causes, and the ONSD increased accordingly. However, we consider that edema was not resolved in survivors within 2 hours, and the treatment would reduce ONSD within a wider period of time. This indicates that patients with severe ONSD elevation have higher risk of death, and this may guide the physician for necessary adjustments in the treatment plan.

There are medical and surgical decompression approaches for cases with ICP increase. Although hypertonic saline and mannitol are therapies to reduce ICP, they may constitute a risk in some cases. However, cases receiving anti-edema therapy needed a longer period for treatment response $\mathrm{e}^{2,39}$. There was no change in ONSD in patients who received anti-edema therapy, and an increase of ONSD was detected in patients who were not treated, probably due to the severity of the TBI as well as the increase of ICP due to secondary causes.

Our study had some limitations; first, vital parameters of the patients were not recorded, and their effects on ICP was not investigated. Second, evaluation of a new lesion (i.e., shift, hemorrhage) and comparison with any former lesion were not performed in control brain CT scan of the patients. Patients who underwent surgical intervention for acute brain injury were not observed within 2 hours; therefore, 
these patients were excluded of the study, preventing the evaluation of the effect of surgical decompression on ONSD. Subgroups (type of anti-edema medication, ventilation rate, elevation status of the head) of the anti-edema therapy and the effect of the treatment were not investigated.
Consequently, ONSD follow-up may be used to monitor ICP increase of the patients with acute TBI. We believe that repetitive ONSD measurements would be useful to determine possible effects of secondary damage and trauma severity during patient treatment.

\section{References}

1. Bar J, Rosenberg J, Chan W, Panebianco N. Pearls \& Oy-sters: Diagnosis and monitoring of elevated intracranial pressure through ultrasound of the optic nerve. Neurology. 2019 Feb;92(6):299-301. https://doi.org/10.1212/WNL.0000000000006888.

2. Marehbian J, Muehlschlegel S, Edlow BL, Hinson HE, Hwang DY. Medical management of the severe traumatic brain injury patient. Neurocrit Care. 2017 Dec;27(3):430-46. https://doi.org/10.1007/ s12028-017-0408-5

3. Dilmen ÖK, Akçıl EF, Tunalı Y. Intensive care treatment in traumatic brain injury. Turk J Anaesthesiol Reanim. 2015 Feb;43(1):1-6. https:// doi.org/10.5152/TJAR.2014.26680

4. Hussain E. Traumatic brain injury in the pediatric intensive care unit. Pediatr Ann. $2018 \mathrm{Jul}$ 1;47(7):e274-9. https://doi. org/10.3928/19382359-20180619-01

5. Vella MA, Crandall ML, Patel MB. Acute management of traumatic brain injury. Surg Clin North Am. 2017 Oct;97(5):1015-30. https://doi. org/10.1016/j.suc.2017.06.003

6. Robba C, Bacigaluppi S, Cardim D, Donnelly J, Bertuccio A, Czosnyka M. Non-invasive assessment of intracranial pressure. Acta Neurol Scand. 2016 Jul;134(1):4-21. https://doi.org/10.1111/ane.12527

7. Sekhon MS, Griesdale DE, Robba C, McGlashan N, Needham E, Walland K, et al. Optic nerve sheath diameter on computed tomography is correlated with simultaneously measured intracranial pressure in patients with severe traumatic brain injury. Intensive Care Med. 2014 Sep;40(9):1267-74. https://doi.org/10.1007/s00134014-3392-7c

8. Luerssen TG, editor Intracranial pressure: current status in monitoring and management. Semin Pediatr Neurol. 1997 Sep;4(3):146-55. https://doi.org/10.1016/s1071-9091(97)80033-2

9. M Czosnyka M, Pickard JD. Monitoring and interpretation of intracranial pressure. Neuroscience for neurologists J Neurol Neurosurg Psychiatry. 2004 Jun;75(6):813-21. https://doi. org/10.1136/jnnp.2003.033126

10. Moretti R, Pizzi B, Cassini F, Vivaldi N. Reliability of optic nerve ultrasound for the evaluation of patients with spontaneous intracranial hemorrhage. spontaneous intracranial hemorrhage. Neurocrit Care. 2009 Dec;11(3):406-10. https://doi.org/10.1007/ s12028-009-9250-8

11. Jenjitranant P, Tunlayadechanont P, Prachanukool T, Kaewlai R. Correlation between optic nerve sheath diameter measured on imaging with acute pathologies found on computed tomography of trauma patients. Eur J Radiol. 2020 Apr;125:108875. https://doi. org/10.1016/j.ejrad.2020.108875

12. Kerscher SR, Schöni D, Hurth H, Neunhoeffer F, Haas-Lude K, Wolff $\mathrm{M}$, et al. The relation of optic nerve sheath diameter (ONSD) and intracranial pressure (ICP) in pediatric neurosurgery practice-Part I: correlations, age-dependency and cut-off values. Childs Nerv Syst. 2020 Jan;36(1):99-106. https://doi.org/10.1007/s00381-019-04266-1

13. Khan MN, Shallwani H, Khan MU, Shamim MS. Noninvasive monitoring intracranial pressure-A review of available modalities. Surg Neurol Int. 2017 Apr;8:51. https://doi.org/10.4103/sni.sni_403_16

14. Kim S-E, Hong EP, Kim HC, Lee SU, Jeon JP. Ultrasonographic optic nerve sheath diameter to detect increased intracranial pressure in adults: a meta-analysis. Acta Radiol. 2019 Feb;60(2):221-9. https:// doi.org/10.1177/0284185118776501

15. Ünlü AR, Ülger F, Dilek A, Barıș S, Murat N, Sarıhasan B. Evaluation of the relationship between revised trauma score, and trauma and injury severity scores with prognosis of trauma patients in intensive care unit. Turk J Anaesthesiol Reanim 2012 Jun;40(3):1 28-35. https:// doi.org/10.5222/JTAICS.2012.128

16. Neklapilová $V$, Zelnícek P. Epidemiology of severe injuries from the viewpoint of the trauma center. Cas Lek Cesk. 2003;142(11):676-8.

17. Ahun E, Köksal Ö, Sığırlı D, Gökhan Torun G, Dönmez SS, Armağan E. Value of the Glasgow coma scale, age, and arterial blood pressure score for predicting the mortality of major trauma patients presenting to the emergency department. Ulus Travma Acil Cerrahi Derg. 2014 Jul;20(4):241-7. https://doi.org/10.5505/tjtes.2014.76399

18. Püsküllüoğlu S, Açıkalın A, Ay M, Kozacı N, Avcı A, Gülen M, et al. Analysis of adult trauma patients admitted to emergency department. Çukurova Med J. 2015 Apr;40(3):569-79.

19. Adıyaman E, Tokur ME, Bal ZM, Gökmen AN, Koca U. Retrospective analysis of trauma patients who were treated and followed in anesthesia intensive care unit. J Turk Soc Intens Care. 2019 Mar:17(3):146-53. https://doi.org/10.4274/tybd.galenos.2018.82905

20. Kara I, Altınsoy S, Gök U, Onur A, Sarıbapıcçı R. Mortality analysis of trauma patients in general intensive care unit of a state hospital. Türk Yoğun Bakım Derneği Dergisi. 2015 Aug;13(2):68-74. https://doi. org/10.4274/tybdd. 54154

21. Ișık HS, Bostancı U, Yıldız Ö, Özdemir C, Gökyar A. Retrospective analysis of 954 adult patients with head injury: an epidemiological study. Ulus Travma Acil Cerrahi Derg. 2011;17(1):46-50. https://doi. org/10.5505/TJTES.2011.57431

22. Lee D, Lee B, Noh S, Cho Y. High fibrin/fibrinogen degradation product to fibrinogen ratio is associated with 28-day mortality and massive transfusion in severe trauma. Eur J Trauma Emerg Surg. 2018 Apr;44(2):291-8. https://doi.org/10.1007/s00068-017-0844-0

23. Faul M, Xu L, Wald MM, Coronado VG. Traumatic Brain Injury in the United States: Emergency Department Visits, Hospitalizations and Deaths 2002-2006. Atlanta (GA): Centers for Disease Control and Prevention, National Center for Injury Prevention and Control; 2010.

24. Dur A, Koçak S, Cander B, Sönmez E, Civelek C. Factors affecting mortality in patients with multitrauma which were treated in intensive care unit. Dicle Tip Dergisi. 2013 Jan;40(2):177-82. https:// doi.org/10.5798/diclemedj.0921.2013.02.0251

25. Isokuortti H, Iverson GL, Silverberg ND, Kataja A, Brander A, Öhman J, et al. Characterizing the type and location of intracranial abnormalities in mild traumatic brain injury. J Neurosurg. 2018 Dec;129(6):1588-97. https://doi.org/10.3171/2017.7.JNS17615.

26. Dunham CM, Malik RJ, Huang GS, Kohli CM, Brocker BP, Ugokwe KT. Hypertonic saline administration and complex traumatic brain injury outcomes: a retrospective study. Int J Burns Trauma. 2018 Jun;8(3):40-53.

27. Siwicka-Gieroba D, Malodobry K, Biernawska J, Robba C, Bohatyrewicz R, Rola R, et al. The neutrophil/lymphocyte count ratio predicts mortality in severe traumatic brain injury patients. $J$ Clin Med. 2019 Sep;8(9):1453. https://doi.org/10.3390/jcm8091453 
28. Legrand A, Jeanjean P, Delanghe F, Peltier J, Lecat B, Dupont H. Estimation of optic nerve sheath diameter on an initial brain computed tomography scan can contribute prognostic information in traumatic brain injury patients. Crit Care. 2013 Mar;17(2):R61. https://doi.org/10.1186/cc12589

29. Naldi A, Pivetta E, Coppo L, Cantello R, Comi C, Stecco A, et al. Ultrasonography monitoring of optic nerve sheath diameter and retinal vessels in patients with cerebral hemorrhage.J Neuroimaging. 2019 May;29(3):394-9. https://doi.org/10.1111/jon.12604

30. Geeraerts T, Launey Y, Martin L, Pottecher J, Vigué B, Duranteau $J$, et al. Ultrasonography of the optic nerve sheath may be useful for detecting raised intracranial pressure after severe brain injury. Intensive Care Med. 2007 Oct;33(10):1704-11. https://doi. org/10.1007/s00134-007-0797-6

31. Lim TK, Yu BC, Ma DS, Lee GJ, Lee MA, Hyun SY, et al. Correlation between optic nerve sheath diameter measured by computed tomography and elevated intracranial pressure in patients with traumatic brain injury. J Trauma Inj. 2017 Dec;30(4):140-4. https:// doi.org/10.20408/jti.2017.30.4.140

32. Komut E, Kozacı N, Sönmez BM, Yılmaz F, Komut S, Yıldırım ZN, et al. Bedside sonographic measurement of optic nerve sheath diameter as a predictor of intracranial pressure in ED. Am J Emerg Med. 2016;34(6):963-7. https://doi.org/10.1016/j.ajem.2016.02.012

33. Vaiman M, Sigal T, Kimiagar I, Bekerman I. Intracranial pressure assessment in traumatic head injury with hemorrhage via optic nerve sheath diameter. J Neurotrauma. 2016 Dec;33(23):2147-53. https://doi.org/10.1089/neu.2015.4293
34. Sönmez BM, Temel E, İșcanlı MD, Yılmaz F, Gülöksüz U, Parlak S, et al. Is initial optic nerve sheath diameter prognostic of specific head injury in emergency departments? J Natl Med Assoc. 2019 Apr;111(2):210-7. https://doi.org/10.1016/j.jnma.2018.10.009.

35. Hon KL, Huang S, Poon WS, Cheung HM, Ip P, Zee B. Mortality and morbidity of severe traumatic brain injuries; a pediatric intensive care unit experience over 15 years. Bull Emerg Trauma. 2019 Jul;7(3):256-62. https://doi.org/10.29252/beat-070308

36. Karakitsos D, Soldatos T, Gouliamos A, Armaganidis A, Poularas J, Kalogeromitros A, et al. Transorbital sonographic monitoring of optic nerve diameter in patients with severe brain injury. Transplant Proc. 2006 Dec;38(10):3700-6. https://doi.org/10.1016/j. transproceed.2006.10.185

37. Al Saiegh F, Philipp L, Mouchtouris N, Chalouhi N, Khanna O, Shah So, et al. Comparison of outcomes of severe traumatic brain injury in 36,929 patients treated with or without intracranial pressure monitoring in a mature trauma system. World Neurosurg. 2020 Apr;136:e535-e541. https://doi.org/10.1016/j. wneu.2020.01.070

38. Thotakura A, Marabathina N, Danaboyina A, Mareddy R. Role of serial ultrasonic optic nerve sheath diameter monitoring in head injury. Neurochirurgie. 2017 Dec;63(6):444-8. https://doi.org/10.1016/j. neuchi.2017.06.001

39. Lazaridis C, Rusin CG, Robertson CS. Secondary brain injury: predicting and preventing insults. Neuropharmacology. 2019 Feb;145(Pt B):145-52. https://doi.org/10.1016/j. neuropharm.2018.06.005 